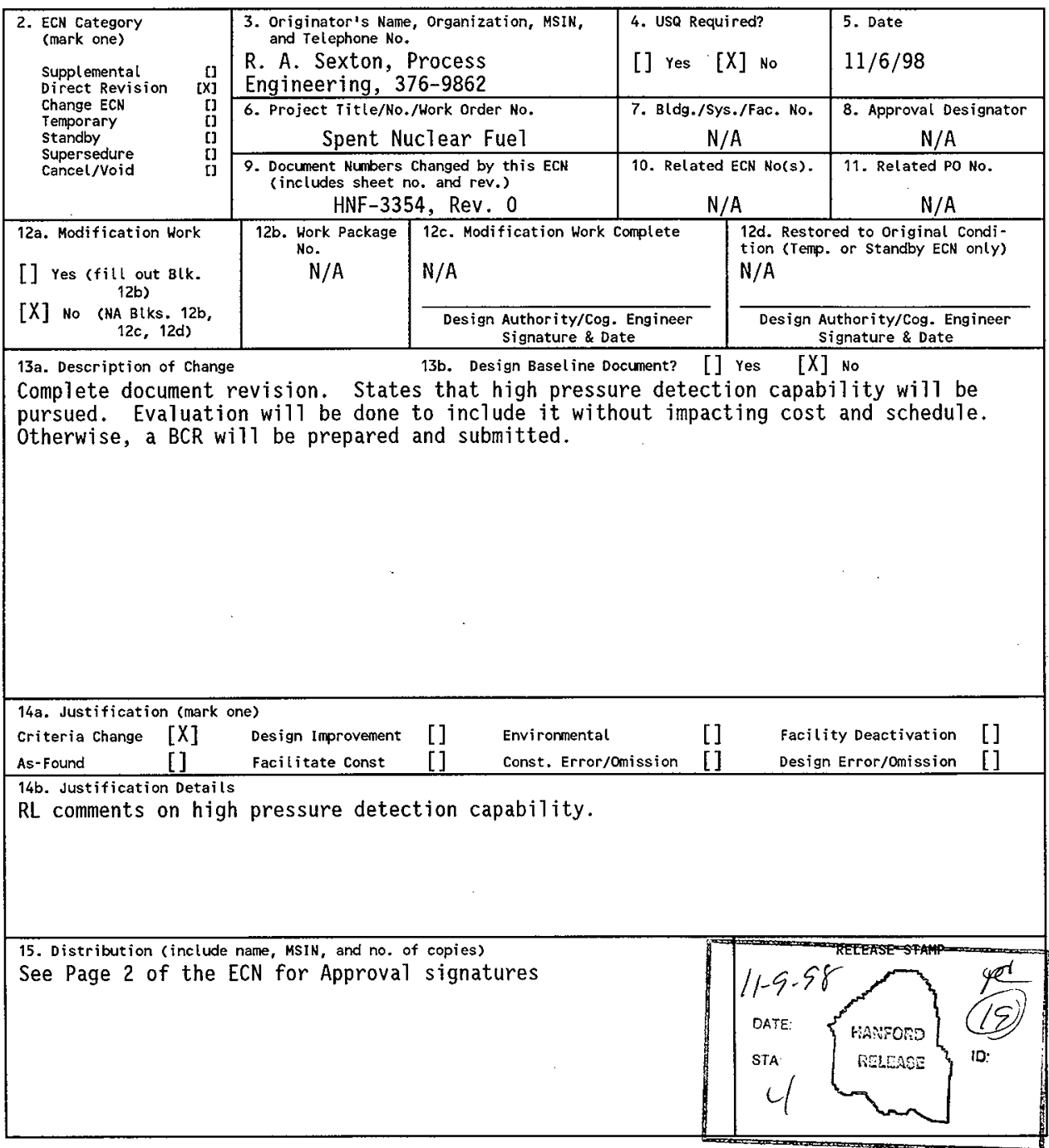




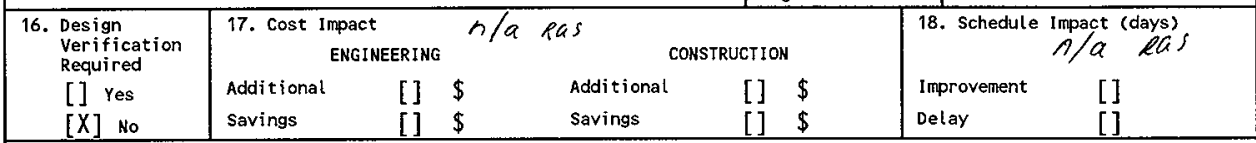

19. Change Impact Review: Indicate the related documents (other than the engineering documents ident ified on Side 1 ) that will be affected by the change described in Block 13 . Enter the affected document number in Block 20.

SDD/DD
Functional Design Criteria
Operating Specification
Criticality Specification
Conceptual Design Report
Equipment Spec.
Const. Spec.
Procurement Spec.
Vendor Information
OM Manual
FSAR/SAR
Safety Equipment List
Radiation Work Permit
Environmental Impact Statement
Environmental Report
Environmental Permit

$\begin{array}{lll}\text { [] } & \text { Seismic/Stress Analysis } & {[]} \\ {[]} & \text { Stress/Design Report } & {[]} \\ {[]} & \text { interface Control Drawing } & {[]} \\ {[]} & \text { Calibration Procedure } & {[]} \\ {[]} & \text { Installation Procedure } & {[]} \\ {[]} & \text { Maintenance Procedure } & {[]} \\ {[]} & \text { Engineering Procedure } & {[]} \\ {[]} & \text { Operating Instruction } & {[]} \\ {[]} & \text { Operating Procedure } & {[]} \\ {[]} & \text { Operational Safety Requirement } & {[]} \\ {[]} & \text { IEFD Drawing } & {[]} \\ {[]} & \text { Cell Arrangement Drawing } & {[]} \\ {[]} & \text { Essential Material Spocification } & {[]} \\ {[]} & \text { Fac. Proc. Samp. Schedule } & {[]} \\ {[]} & \text { Inspection Plan } & {[]} \\ {[]} & \text { Inventory Adjustment Request } & {[]}\end{array}$

[]
[]
[]
[]
[]
[]
[]
[]
[]
[]
[]
[]
[]
[]
[]
[]

Tank Calibration Manual

Health Physics Procedure

Spares Multiple Unit Listing

Test Procedures/Specification

Component Index

ASME Coded Item

Human Factor Consideration

Computer Software

Electric Circuit Schedule

ICRS Procedure

Process Control Manual/Plan

Process Flow Chart

Purchase Requisition

Tickler File

20. Other Affected Documents: (NOTE: Documents listed below will not be revised by this ECN.) Signatures below indicate that the signing organization has been notified of other affected documents listed below. Document Number/Revision

HNF-3312, Rev. 0

\section{Approvals}

Design Authority

Cog. Eng. R. A. Sexton P. R.

Cog. Mgr. S. R. Frederickson of Ruluni

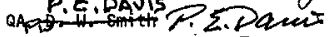

safety R. P. Omberg 7206 pratury

Environ.

other

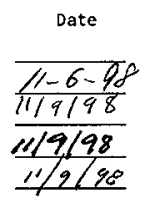

Design Agent

Signature

Date
PE

QA

Safety

Design

Environ.

other

\section{DEPARTMENT OF ENERGY}

Signature or a Control Number that tracks the Approval Signature

ADDITIONAL

\begin{tabular}{l} 
] \\
] \\
] \\
] \\
] \\
] \\
] \\
] \\
] \\
] \\
] \\
] \\
] \\
] \\
\hline
\end{tabular}




\title{
MCO MONITORING ISSUE CLOSURE PACKAGE
}

\author{
R. A. Sexton*
}

DE\&S Hanford, Inc., Richland, WA 99352

U.S. Department of Energy Contract DE-AC06-96RL13200

$\begin{array}{ll}\text { EDT/ECN: ECN }-651402 & \text { UC: } 510 \\ \text { Org Code: } 2 F 300 & \text { Charge Code: } 105355 \\ \text { B\&R Code: EW704000 } & \text { Total Pages: } 8\end{array}$

Key Words: MCO Monitoring, Spent Nuclear Fuel, Technical Issue Closure

Abstract: Agreement on a focused, limited approach to MCO monitoring has been documented. While the value of monitoring has been understood by those interested in the SNF Project, there had been a diversity of opinion on details of approach and implementation. For this reason, MCO monitoring had been identified as a technical issue. A cooperative effort involving the contractor, RL, and the technical assistance group (TAG), resulted in the definition of an approach agreeable to all and of the remaining details to be resolved through conceptual engineering. MCO monitoring will consist of temperature, pressure, and gas composition monitoring of 4 to 6 MCOs for up to two years. High pressure detection capability for the duration of interim storage for every MCO will also be evaluated and implemented within the current project baseline, if possible. Otherwise a BCR will be prepared and submitted.

*Technical Resources Internationa1, Inc., Richland, WA.

TRADEMARK DISCLAIMER. Reference herein to any specific commerciat product, process, or service by trade name, trademark, manufacturer, or otherwise, does not necessarily constitute or imply its endorsement, recommendation, or favoring by the United States Government or any agency thereof or its contractors or subcontractors.

Printed in the United States of America. To obtain copies of this document, contact: Document Control Services, P.O. Box 950, Maitstop H6-08, Richland WA 99352, Phone (509) 372-2420; Fax (509) 376-4989.
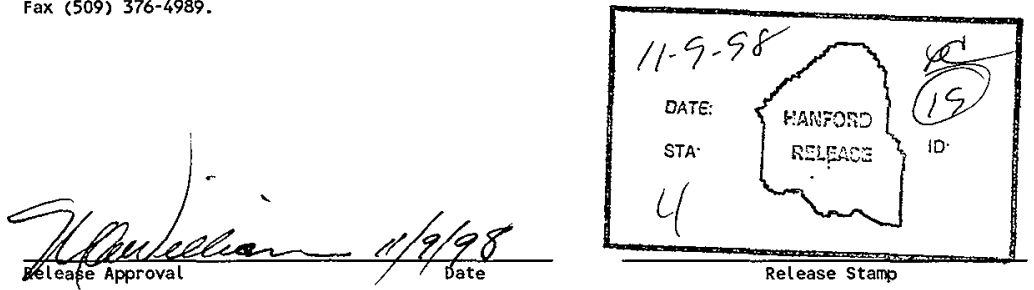


\section{RECORD OF REVISION}

(2) Title

MCO MONITORING ISSUE CLOSURE PACKAGE

CHANGE CONTROL RECORD

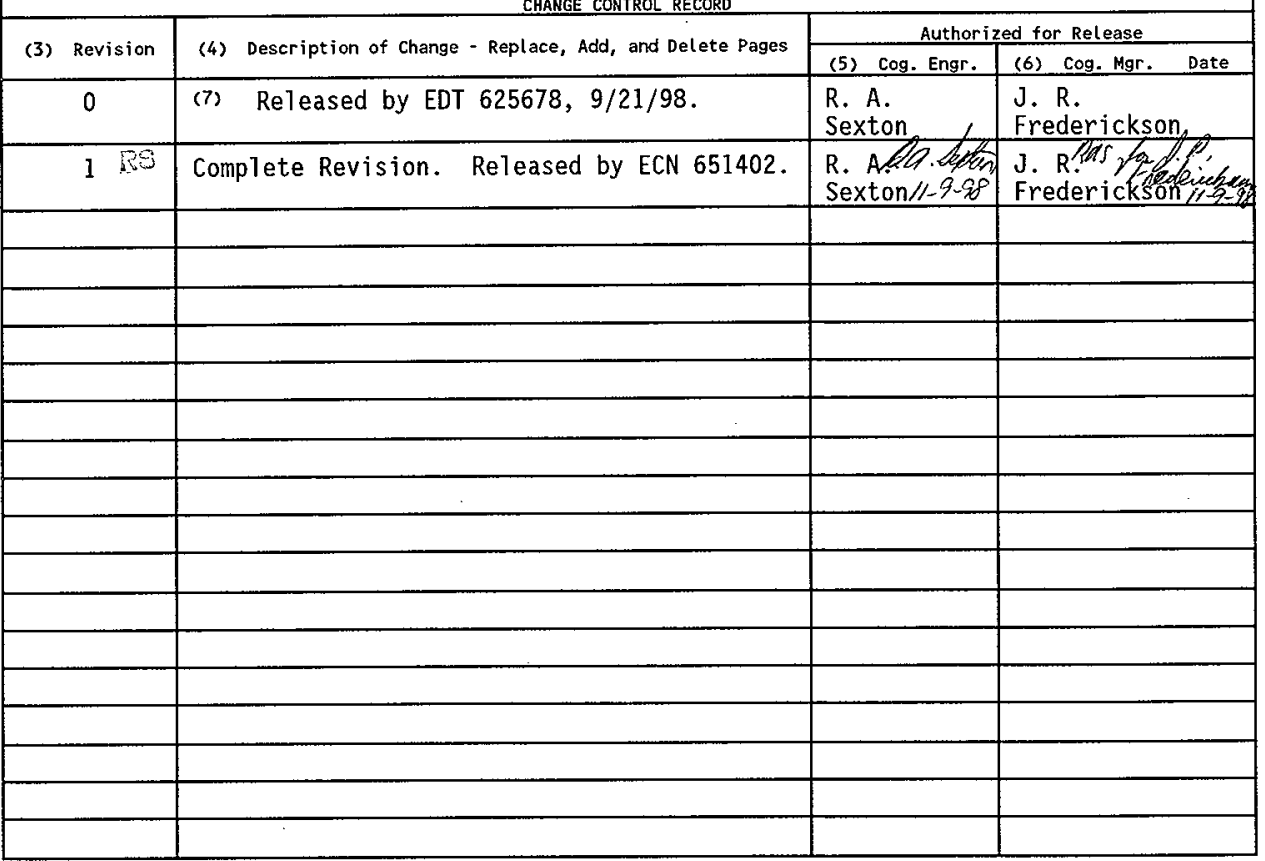


HNF-3354, Rev. 1

TABLE OF CONTENTS

1.0 SUMMARY . $\quad . \quad$. $\quad . \quad . \quad . \quad . \quad . \quad . \quad$.

2.0 STATEMENT OF ISSUE . . . . . . . . . 3

3.0 BASIS OF CLOSURE $\quad$. $\quad$. $\quad$. . . . . . . . 3

4.0 DISCUSSION $\quad . \quad$. $\quad . \quad . \quad . \quad . \quad . \quad . \quad 4$

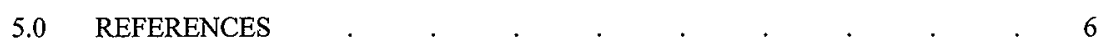


HNF-3354, Rev. 1

Issue Closure Package

Issue: MCO Monitoring

Lead:

R. A. Sexton

Approvals:

Chief Engineer:

A. M. Segrest

Technical Operations:

J. A. Swenson

Process Engineering:

J. R. Frederickson

Nuclear Safety:

R. G. Morgan

MCO Design Authority:

L. H. Goldman

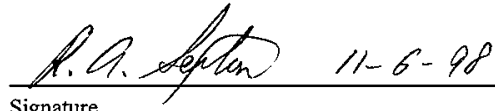

Signature
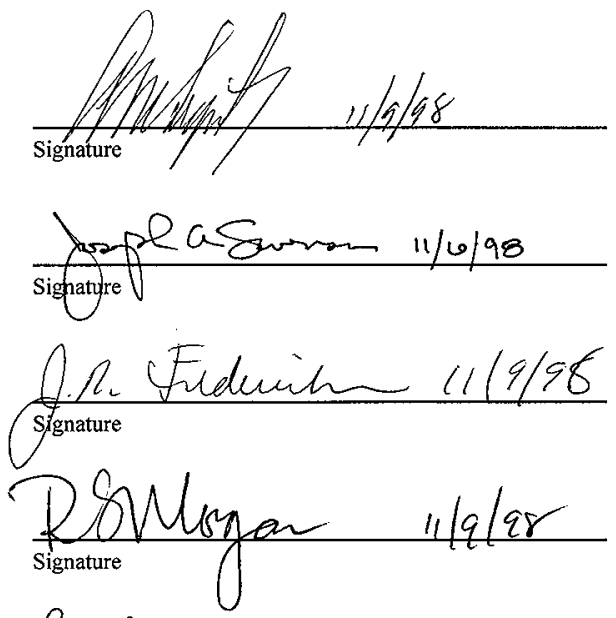

chis teton n/6/98

Signature

2 
HNF-3354, Rev. 1

\subsection{Summary}

Agreement on a focused, limited approach to MCO monitoring has been documented. While the value of monitoring has been understood by those interested in the SNF Project, there had been a diversity of opinion on details of approach and implementation. For this reason, MCO monitoring had been identified as a technical issue. A cooperative effort involving the contractor, DOE-RL, and the Technical Assistance Group (TAG), resulted in the definition of an approach agreeable to all and definition of the remaining details to be resolved through conceptual engineering. MCO monitoring will consist of temperature, pressure, and gas composition monitoring of 4 to $6 \mathrm{MCO}$ for up to two years. High pressure detection capability for the duration of interim storage for every $\mathrm{MCO}$ will also be evaluated and implemented within the existing project baseline, if possible. Otherwise, a BCR will be prepared and submitted.

\subsection{Statement of the Issue}

Monitoring of MCOs during interim storage to obtain data on the finished product is of interest to the SNF Project. However, there has been a diversity of opinion on the appropriate objectives, strategy, and key elements of a monitoring program. Agreement was needed on an approach which provides useful data without unacceptable impact on the project cost and schedule or upon the fundamental project objective of putting spent nuclear fuel in a safe configuration away from the river.

\subsection{Basis of Closure}

An approach to monitoring has been agreed upon and documented in Sexton, 1998. That document represents a cooperative effort of the contractor, DOE-RL, and the TAG.

The key provisions of Sexton, 1998, are:

1. Once the MCOs have been placed in storage, there is no safety requirement or regulatory requirement to monitor them. Neither is there a precedent for monitoring internal parameters of spent fuel containers. However, a limited monitoring program is considered valuable because a) It is good engineering practice to acquire data at a reasonable cost which may be useful in developing a fuller understanding of the engineered system, and b) Previous investigations have been limited to small fuel samples or simulant prototypes and have been relatively short in duration. MCO monitoring can provide data on large loads of actual fuel, in full scale configuration, over longer time periods. Additional knowledge of this fuel type may prove valuable in future analyses or applications.

2. Observation and sampling of MCOs after CVD would be limited to 4 to $6 \mathrm{MCOs}$, for up to two years, monitoring for temperature and pressure, and sampling gas composition. 
3. High pressure detection capability for the duration of interim storage for every $\mathrm{MCO}$ is desirable and is being evaluated. It will be implemented within the current project baseline if possible. Otherwise, a BCR will be prepared and submitted.

4. The goal is to do nothing that will adversely affect the primary project objectives, the SAR schedule, or the MCO pressure capability.

Further conceptual engineering is required to assess:

1. Location and method of gas sampling. Of primary interest is whether the gas sampling will be done in-situ or in the sampling/welding station.

2. Method of temperature and pressure monitoring.

3. Feasibility and method of high pressure detection capability.

\subsection{Discussion}

A limited program of MCO monitoring to be done in the sampling/welding station of the CSB had been provided for in the project baseline. However, the objectives of the monitoring program needed to be clearly documented. The safety basis of the project does not rely on monitoring in the CSB. Further, there is no regulatory requirement for monitoring. Monitoring in the CSB does not provide timely data for process control or process validation. However, since the SNF Project is developing a unique engineered system, obtaining data on the finished product, if it can be done at reasonable cost, is considered good engineering practice. There has been no previous opportunity to obtain data on large loads of actual fuel, in full scale configuration, over time periods longer than a year.

The duration of monitoring recommended is based on being long enough to include a full annual thermal cycle in the CSB, but completed in time to weld the MCO closure and store the monitored MCO prior to SNF Project completion.

The number of MCOs recommended, six, is considered enough to provide useful data, but small enough to be practical and not be a hindrance to the primary project objectives. If each MCO is considered a unit of production, many more MCOs than is practical would need to be monitored to be statistically significant. However, each MCO contains as many as 270 fuel assemblies. Thus monitoring a small number of MCOs will provide an opportunity for data from fuel totaling more than 1000 fuel elements, a quantity much larger than that used in earlier characterization activities.

High pressure detection capability is considered desirable over the duration of interim storage. However, an assessment of technology is needed to determine whether a method exists which 
HNF-3354, Rev. I

will provide useful information after 40 years without diminishing the MCO pressure capability or safety. This application will not permit technology which is developmental, requires maintenance or routine inspection, or which is adversely affected by radiation.

Sampling and monitoring in the sampling/welding station is already provided for in the design. More significant design changes are expected to be needed for in-situ gas sampling capability than for in-situ temperature and pressure monitoring. Therefore the location of gas sampling will be evaluated. The cost/schedule impacts of providing in-situ capability must be weighed against the benefit of reduced MCO movement. The frequency of gas sampling would not be affected by the location.

Deviation Notice 98-579 has been prepared to identify the cost and schedule associated with the conceptual engineering needed to implement the proposed monitoring approach and to complete evaluation of the open questions identified above. 


\section{HNF-3354, Rev. 1}

\subsection{References}

Sexton, R. A., 1998, "MCO Monitoring Activity Description," HNF-3312, Rev. 1, DE\&S Hanford, Richland, Washington

SNF Project Deviation Notice 98-579, "Evaluation and Conceptual Design for MCO Monitoring at the CSB." 


\section{DISTRIBUTION COVERSHEET}

Subject: MCO ISSUE PAPERS PER ATTACHED DISTRIBUTION INDEX

\section{DISTRIBUTION}

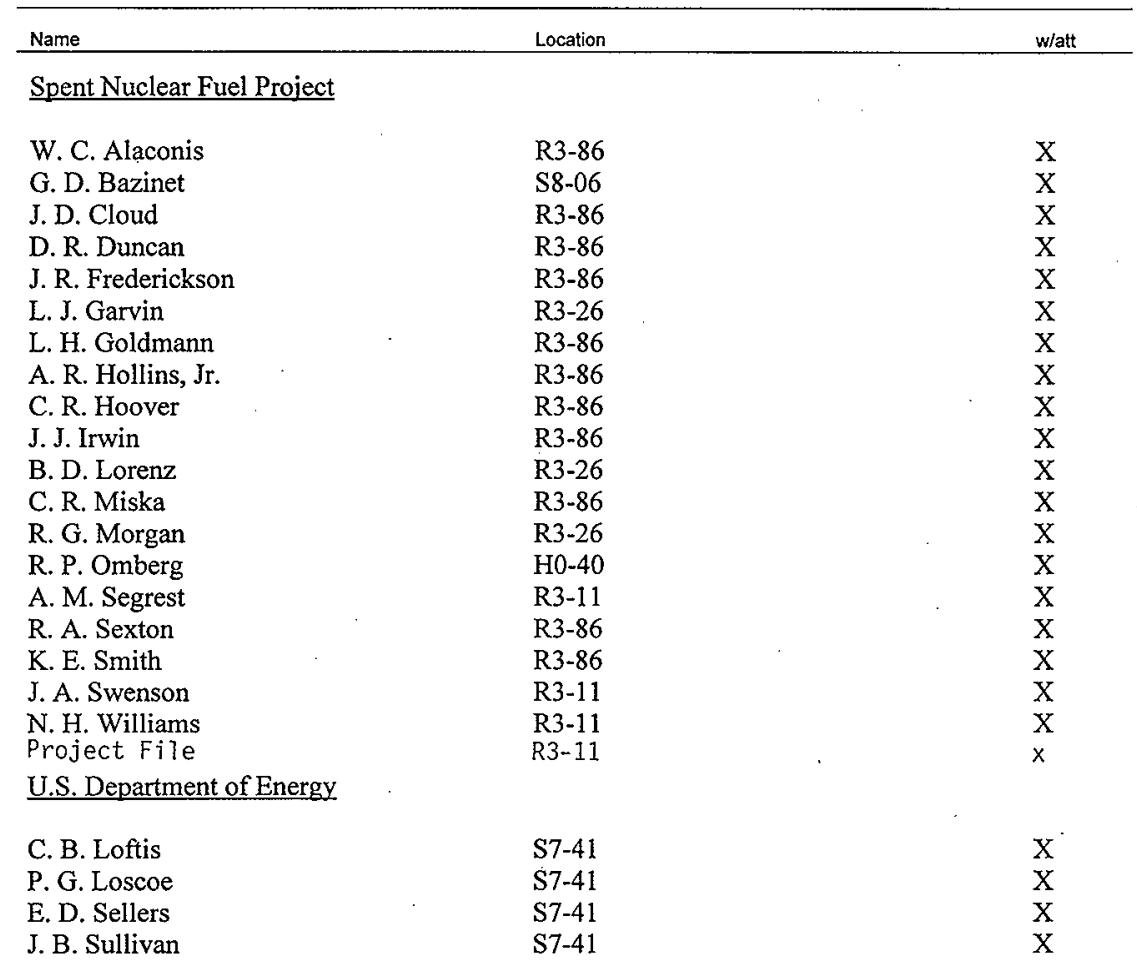




\section{DISTRIBUTION INDEX}

The Multi-Canister Overpack Issue papers listed below are being distributed as a package to facilitate future reference and use by SNF Project personnel. The following issue papers are attached:

1. HNF-2876, Oxygen Gettering Issue Closure Package

2. HNF-3265, MCO Number of Shield Plug Ports

3. HNF-3399, MCO Necessity of the Rupture Disk

4. HNF-3267, MCO Dual Pressure Rating

5. HNF-3293, MCO Ultrasonic Examination of Closure Weld

6. HNF-3354, MCO Monitoring Issue Closure Package and HNF-3312, MCO

Monitoring Activity Description

7. HNF-3292, MCO Sealing Configuration

8. HNF-3266, MCO Design Pressure Rating

9. HNF-3255, ASME Code Requirements for MCO Design and Fabrication

10. HNF-3398, MCO Inservice Inspection and Maintenance

11. HNF-3420, MCO Internal HEPA Filters

12. HNF-3036, Low Reactive Surface Area Issue Closure Package

13. HNF-3270, MCO Pressure Testing 